\title{
STUDY OF MEAN PLATELET VOLUME VERSUS LEUCOCYTE ESTERASE AS A MARKER IN DIAGNOSIS OF SPONTANEOUS BACTERIAL PERITONITIS
}

\author{
By

\section{Amer Abd EL-Hamid Gomaa*, Ali Ibrahim Ali Soliman*, Ahmad Hasan Muhammad Salim** and Mahmoud Bastawy Ismaeil***} \\ *Gastroenterology and Hepatology, Faculty of Medicine, Al-Azhar University \\ **Gastroenterology and Hepatology department in Nasser Institute \\ ***Clinical Pathology, Faculty of Medicine, Al-Azhar University \\ Correspondence to: Dr. Ali Ibrahim Ali Soliman.
}

\begin{abstract}
Background: Spontaneous bacterial peritonitis (SBP) is a severe and frequent complication of cirrhosis with a high mortality rate. Early diagnosis and treatment of SBP is necessary for survival.

Objective: To study the mean platelet volume (MPV) versus leucocyte esterase as a marker in diagnosis of decompensated cirrhotic patients with spontaneous bacterial peritonitis.

Patients and methods: A total of 200 patients with decompensated liver cirrhosis and ascites, were admitted to the Department of Gastroenterology and Hepatology in Nasser Institute, and were enrolled in this study between January 2016 and October 2017. Patients were divided into two equal groups; group (I) was diagnosed non SBP and group (II) was diagnosed SBP. All patients underwent abdominal paracentesis, and the ascitic fluid was processed for cell count, leukocyte esterase reagent strip test (LERS) (URIT 10V) and culture. All patients underwent assessment of MPV in CBC.

Results: Diagnostic performance of mean platelet volume showed that we can use MPV as a good diagnostic marker for SBP with sensitivity $75 \%$, specificity $99 \%$ and accuracy $93.2 \%$. The best cut off value for discriminating patients with SBP from patients without SBP was $9.2 \mathrm{fl}$. The test of ascetic fluid by leukocyte esterase reagent strips showed that specificity $=93 \%$, sensitivity $=80 \%$, positive predictive value $(\mathrm{PPV})=$ $92 \%$, negative predictive value $(\mathrm{NPV})=82.3 \%$ and accuracy $=86.5 \%$.
\end{abstract}

Conclusion: MPV and LERS can be used as a good marker in diagnosis of SBP in cirrhotic patients with ascites.

Keywords: Cirrhosis, ascites, spontaneous bacterial peritonitis, mean platelet volume, leucocyte esterase.

\section{INTRODUCTION}

Ascites is the most common complication in decompensated cirrhotic patients. Approximately, 50\% of patients with compensated cirrhosis will develop ascites over a 10 -years period and $50 \%$ will show only two years survival from the onset of ascites (Hadhoud et al., 2012). SBP is a bacterial infection of the ascitic fluid without any intra-abdominal source of infection (Ponziani et al., 2018). The prevalence of SBP in cirrhotic patients with ascites has been estimated at 
$10 \%$ to $30 \%$ (Runyon, 2009). Patients with cirrhosis and ascites show a higher susceptibility to bacterial infections mainly because of the inadequate defence mechanisms. The most frequent and the most severe one being SBP (Cai et al., 2019). There are some mechanisms that are being proposed to explain bacterial translocation (BT) in cirrhosis: the intestinal bacterial overgrowth, the structural and functional alterations of the intestinal mucosal barrier and the deficiency of the local immune response. For SBP diagnosis, the number of polymorph nuclear leucocytes (PMNL) from the ascitic fluid obtained by paracentesis must exceed 250cells/mm3 and from bacteriological cultures only one germ must be isolated (Sánchez, 2015). However, because of the organization of facilities in many hospitals, a bacteriological laboratory is not always available for all departments admitting cirrhotic patients with ascites. It follows that alternative methods for rapid diagnosis of SBP are an urgent requireme (Mendler et al., 2010 and Shizuma, 2018). Leukocyte esterase is an enzyme secreted by activated neutrophils that have been recruited to areas of infection and can be used as inflammatory marker (Parvizi et al., 2011). Use of reagent strip testing for leucocytes esterase has been proposed to reduce the time from paracentesis to a presumptive diagnosis of SBP from a few hours to a few seconds (Mendler et al., 2010 and Chugh et al., 2015). Platelets are considered an important source of prothrombotic agents associated with inflammatory markers and play a role in the initiation and propagation of vascular and inflammatory diseases (Abdel-Razik et al., 2014). Two different studies have found increase in MPV levels in cirrhotic patients with Ascitic fluid infection (AFI) and proposed it as an accurate diagnostic test to predict AFI; nevertheless, these two studies differ in their proposed cut off values, and found different sensitivity, specificity and predictive values. Therefore, new studies should be carried out to determine if there is a difference between MPV value in cirrhotic patients without infection and cirrhotic patients with AFI and to identify a MPV cut off value which could be able to predict the presence of bacterial infection in cirrhotic patients (Suvak et al., 2015).

The aim of this work was to study the Mean Platelet Volume (MPV) versus Leucocyte Esterase as a marker in diagnosis of spontaneous bacterial peritonitis.

\section{PATIENTS AND METHODS}

This was a prospective analytic study which was carried out at the Department of Gastroenterology and Hepatology in Nasser Institute between January 2016 and October 2017 after acceptance of our scientific and ethical committees, and written consents from all patients before their recruitment in the study.

This study included two hundred patients (200) with ascites due to decompensated liver cirrhosis with different etiologies. All patients were divided into two equal groups; Group I (non SBP), and Group II (SBP). SBP group was diagnosed by fever, generalized abdominal pain and tenderness, PMN in ascitic fluid $\geq 250$ cells $/ \mathrm{mm} 3$ ) and at least one isolated organism from ascitic culture. 


\section{Exclusion Criteria:}

Hemorrhagic ascites, secondary peritonitis, immunocompromised patients, e.g. pregnancy, patients under chemotherapy and HIV, patients who had received antibiotics before hospital admission (10 days before), patients with heart failure or ischemic heart, diabetes mellitus, hypertension, hyperlipidemia hematological disorders, e.g. leukemia, myeloprolifrative diseases and aplastic anemia, neoplastic disorders, patients with clinically overt hypothyroidism, hyperthyroidism, patients with clinically and laboratory-evident autoimmune diseases, and none of the study participants had received anticoagulant medications, NSAIDs, or oral contraceptive drugs 10 days before hospital admission.

\section{Methods:}

All patients were subjected to full medical history, through physical examination, laboratory investigations, i.e. Complete blood count (CBC) including MPV, prothrombin time (PT), liver functions tests (Total plasma proteins, serum albumin, ALT, AST, total and direct serum bilirubin and alkaline phosphatase), renal function tests (serum creatinine, urea and blood urea nitrogen), electrolytes $(\mathrm{K}, \mathrm{Na}$ and $\mathrm{Ca})$, serum alpha feto protein (AFP), and ascitic fluid analysis including white blood cells $/ \mathrm{mm} 3$ with absolute neutrophil count $/ \mathrm{mm} 3$, ascitic fluid total protein and albumin, bacteriological culture with sensitivity, cytological examination and leucocyte esterase in ascetic fluid by leucocyte esterase reagent strips. All patients were subjected to pelvi-abdominal ultrasound. The diagnosis of SBP was made on the basis of the presence of at least 250 cells/ $\mathrm{mm} 3$ polymorph nuclear leukocyte (PMN) in the Ascitic fluid, with positive ascitic fluid culture.

\section{Sampling:}

1. Blood $(5 \mathrm{ml})$ was withdrawn by venipuncture; $1 \mathrm{ml}$ was stored in an sodium citrate tube for complete blood count, and $4 \mathrm{ml}$ was stored in a plastic tube and allowed to clot. Nonhemolyzed sera were separated will be used for the determination of creatinine, uric acid, C-reactive protein (CRP), and liver functions.

2. An ascitic fluid sample was obtained by paracentesis performed under aseptic conditions from a puncture site in the left or the right lower quadrant with the patient in the supine position. Immediately after the paracentesis, ascitic fluid was tested using LERS designed for urine testing (URIT 10V). The strip was totally immersed in the ascitic fluid sample and immediately removed. Ninety seconds later, the color of the reagent area on the strip was compared with a color chart on the bottle (Abdel-Razik et al., 2014). A five grades colorimetric scale (0-4) was used to record the result. Test was considered positive when read purple. The manufacturer suggests a relationship between PMNL and color scale as follows.

\begin{tabular}{|l|l|l|}
\hline grade 0 & light yellow & negative \\
\hline grade 1 & light pink & $\mathbf{\pm 1 5} \mathrm{PMNL} / \mathrm{uL}$ \\
\hline grade 2 & pink & $>$ 70 $\mathrm{PMNL} / \mathrm{uL}$ \\
\hline grade 3 & light purple & $>125 \mathrm{PMNL} / \mathrm{uL}$ \\
\hline grade 4 & purple & $>500 \mathrm{PMNL} / \mathrm{uL}$ \\
\hline
\end{tabular}




\section{Statistical analysis:}

The collected data were reviewed and coded then analysed by SPSS statistical software version 10.0 (SPSS Inc. Chicago. 1L, USA) was used for data analysis. Two types of data were present; Quantitative data were represented as arithmetic means and standard deviations (means $\pm \mathrm{SD}$ ); the "t test" was used for comparison between two groups and Mann-Whitney U test (for not normally distributed data), and
Qualitative data were represented as frequencies and percents. Chi square test (x2) was carried out for calculating significant relations between groups. Receiver operating characteristic (ROC) curves were constructed for sensitivity, specificity, positive predictive value and negative predictive value. A significant probability ( $p$-value) which considered statistically significant was $<0.05$.

\section{RESULTS}

This study included two hundred patients (200) with ascites due to decompensated liver cirrhosis with different etiologies. All patients were divided into two equal groups; Group (I) was diagnosed non SBP and, group (II) was diagnosed SBP. Group (I) were 66 male patients $(66 \%)$, and 34 female patients $(34 \%)$ with mean \pm SD age $54.58 \pm 10.16$, and group (II) were 58 male patients $(58 \%)$ and 42 female patients $(42 \%)$ with mean \pm SD age 53.22 \pm 8.57 (Table 1).

As regards three of the studied parameters (fever, abdominal pain and hepatic encephalopathy): There was significant statistical difference between the two groups as regard fever and abdominal pain and there was no significant statistical difference as regard hepatic encephalopathy (Table 1).

As regard child-paugh score there was no significant statistical difference between the two groups (Table 1). There was significant statistical difference between the two groups as regard results of ascitic fluid analysis including total leucocytic count, absolute neutrophilic count and total protein (Table 1). There was a significant statistical difference between the two groups as regard culture and sensitivity of ascitic fluid with isolated organisms as follow; E.coli, klebsiella and negative $0(0 \%), 0(0 \%)$ and $100(100 \%)$ respectively in group I and E.coli, klebsiella and negative 59 (59\%), $20(20 \%)$ and $21(21 \%)$ respectively in group II with (Table 1).

Ascitic fluid analysis by dipstick method using LERS revealed 93 patients (93\%) were negative and 7 (7\%) patients were positive in group I and 20 patients (20\%) negative and $80(80 \%)$ were positive in group II with significant statistical difference between the two groups (Table 1).

In this study there was significant statistical difference between the two groups as regard results of mean platelet volume (MPV) which revealed Mean 7.95 with $\mathrm{SD} \pm 0.75$ in group I and Mean 10 with $\mathrm{SD} \pm 1$ in group II (Table 1). 
Table (1): comparison between group (I) and group (II) as regard demographic data, clinical symptoms, child score, LERS, MPV and analysis of ascitic fluid

\begin{tabular}{|c|c|c|c|c|c|c|}
\hline \multirow{2}{*}{\multicolumn{2}{|c|}{ Parameters $\quad$ Groups }} & \multicolumn{2}{|c|}{$\begin{array}{c}\text { Group I } \\
\text { No. }=100\end{array}$} & \multicolumn{2}{|c|}{$\begin{array}{l}\text { Group II } \\
\text { No.=100 }\end{array}$} & \multirow{2}{*}{$\begin{array}{c}\begin{array}{c}\text { Chi square } \\
\text { test }\end{array} \\
\text { P-value } \\
\end{array}$} \\
\hline & & No. & $\%$ & No. & $\%$ & \\
\hline \multirow{2}{*}{ Gender } & Female & 34 & $34.0 \%$ & 42 & $42.0 \%$ & \multirow{2}{*}{$>0.05$} \\
\hline & Male & 66 & $66.0 \%$ & 58 & $\mathbf{5 8 . 0 \%}$ & \\
\hline Age & Mean \pm SD & \multicolumn{2}{|c|}{$54.58 \pm 10.16$} & \multicolumn{2}{|c|}{$53.22 \pm 8.57$} & $>0.05$ \\
\hline \multirow{2}{*}{ Fever } & Negative & 76 & $76.0 \%$ & 37 & $37.0 \%$ & \multirow{2}{*}{$<0.001$} \\
\hline & positive & 24 & $24.0 \%$ & 63 & $63.0 \%$ & \\
\hline \multirow{2}{*}{$\begin{array}{l}\text { Abdominal } \\
\text { pain }\end{array}$} & Negative & 67 & $67.0 \%$ & 22 & $22.0 \%$ & \multirow{2}{*}{$<0.001$} \\
\hline & positive & 33 & $33.0 \%$ & 78 & $78.0 \%$ & \\
\hline \multirow{2}{*}{$\begin{array}{l}\text { Hepatic } \\
\text { encephalopathy }\end{array}$} & Negative & 92 & $92.0 \%$ & 89 & $89.0 \%$ & \multirow{2}{*}{$>0.05$} \\
\hline & positive & 8 & $8.0 \%$ & 11 & $11.0 \%$ & \\
\hline \multirow{3}{*}{$\begin{array}{l}\text { Child-paugh } \\
\text { score }\end{array}$} & Child A & 3 & $3.0 \%$ & 2 & $2.0 \%$ & \multirow{3}{*}{$>0.05$} \\
\hline & Child B & 71 & $71.0 \%$ & 64 & $64.0 \%$ & \\
\hline & Child C & 26 & $26.0 \%$ & 34 & $34.0 \%$ & \\
\hline \multirow{3}{*}{$\begin{array}{l}\text { Culture and } \\
\text { sensitivity }\end{array}$} & E Coli & $\mathbf{0}$ & $0.0 \%$ & 59 & $59.0 \%$ & \multirow{3}{*}{$<0.001$} \\
\hline & klebsiella & $\mathbf{0}$ & $0.0 \%$ & 20 & $20.0 \%$ & \\
\hline & Negative & 100 & $100.0 \%$ & 21 & $21.0 \%$ & \\
\hline \multirow{2}{*}{ LERS } & Negative & 93 & $93.0 \%$ & 20 & $20.0 \%$ & \multirow{2}{*}{$<0.001$} \\
\hline & Positive & 7 & $7.0 \%$ & 80 & $80.0 \%$ & \\
\hline MPV & Mean \pm SD & \multicolumn{2}{|c|}{$7.95 \pm 0.75$} & \multicolumn{2}{|c|}{$10 \pm 1$} & $<0.001$ \\
\hline \multicolumn{6}{|l|}{ 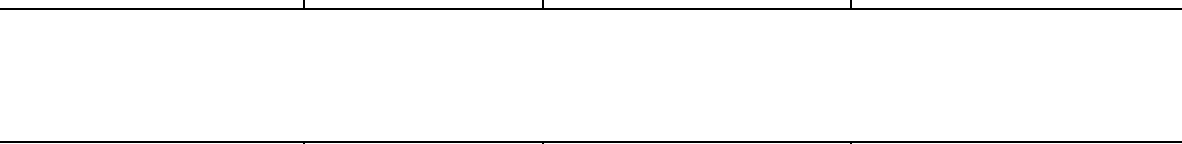 } & $\begin{array}{l}\text { Mann } \\
\text { Whitney } \\
\text { test }\end{array}$ \\
\hline $\begin{array}{l}\text { TLC in ascitic } \\
\text { fluid }\end{array}$ & Mean \pm SD & \multicolumn{2}{|c|}{$255.22 \pm 150.78$} & \multicolumn{2}{|c|}{$1697.69 \pm 1479.90$} & 0.001 \\
\hline $\begin{array}{l}\text { ANC in ascitic } \\
\text { fluid }\end{array}$ & Mean \pm SD & \multicolumn{2}{|c|}{$134.19 \pm 85.69$} & \multicolumn{2}{|c|}{$1024.62 \pm 1033.21$} & 0.001 \\
\hline $\begin{array}{l}\text { Protein in } \\
\text { ascitic fluid }\end{array}$ & Mean \pm SD & \multicolumn{2}{|c|}{$1.89 \pm 0.80$} & \multicolumn{2}{|c|}{$2.42 \pm 0.61$} & 0.001 \\
\hline
\end{tabular}

LERS: leucocyte esterase reagent strips; MPV: mean platelet volume; TLC: total leucocytes; ANC: absolute neutrophilic count

A reagent strip results revealed true positive cases (80), false positive cases (7) true negative cases (93), false negative cases (20), sensitivity $=80 \%$, specificity
$=93 \%$, positive predictive value $(\mathrm{PPV})=$ $92 \%$, negative predictive value (NPV) $=$ $82.3 \%$ with accuracy $=0.865$ (Table 2 ). 
AMER ABD EL-HAMID GOMAA et al.,

Table (2): Validity scores of the leucocyte esterase reagent strips in the diagnosis of SBP between group (I) and group (II)

\begin{tabular}{|c|c|c|c|c|}
\hline $\begin{array}{ll}\text { LERS } & \text { Groups } \\
\end{array}$ & Non SBP (I) & SBP (II) & Total & P-value \\
\hline \begin{tabular}{l|l} 
& Test +ve
\end{tabular} & 7 & 80 & 87 & \multirow{3}{*}{$<0.001$} \\
\hline Test-ve & 93 & 20 & 113 & \\
\hline Total & 100 & 100 & 200 & \\
\hline
\end{tabular}

\begin{tabular}{|c|c|c|c|c|}
\hline AUC & Sensitivity & Specificity & PPV & NPV \\
\hline $\mathbf{0 . 8 6 5}$ & $\mathbf{8 0 . 0 0}$ & 93.00 & 92.0 & 82.3 \\
\hline
\end{tabular}

AUC: area under curve; PPV: positive predictive value; NPV: negative predictive value

In this study, there was significant statistical difference between the two groups as regard comparison between results of LERS in ascitic fluid and results of ascetic fluid analysis (Table 3).

Table (3): Comparison between results of LERS and results of ascitic fluid analysis

\begin{tabular}{|l|c|c|c|c|c|}
\hline \multirow{2}{*}{} & \multicolumn{2}{|c|}{$\begin{array}{c}\text { Negative LERS } \\
\text { N0.=113 }\end{array}$} & \multicolumn{2}{c|}{$\begin{array}{c}\text { Positive LERS } \\
\text { N0.=87 }\end{array}$} & \multirow{2}{*}{ P-value } \\
\cline { 2 - 6 } & Mean & SD & Mean & SD & \\
\hline \multirow{2}{*}{ TLC in ascitic fluid } & 632.89 & $\begin{array}{c}1123.3 \\
6\end{array}$ & $\begin{array}{c}1422.7 \\
\text { 0 }\end{array}$ & 1325.54 & 0.001 \\
\hline ANC in ascitic fluid & 422.93 & $\mathbf{8 4 8 . 1 8}$ & $\mathbf{8 2 2 . 4 7}$ & $\mathbf{8 6 2 . 8 9}$ & $\mathbf{0 . 0 0 1}$ \\
\hline Protein in ascitic fluid & 1.95 & $\mathbf{0 . 7 5}$ & $\mathbf{2 . 4 2}$ & $\mathbf{0 . 6 9}$ & $\mathbf{0 . 0 0 1}$ \\
\hline
\end{tabular}

Comparison between MPV and all studied parameters in group (I) and group (II) show and that there wed no statistically significant difference (Table 4). 
Table (4): Correlation between MPV among all studied parameters in group (I) and group (II)

\begin{tabular}{|l|c|c|c|c|}
\hline \multirow{2}{*}{$\begin{array}{c}\text { Mean platelet } \\
\text { volume }\end{array}$} & \multicolumn{4}{|c|}{ Mean platelet volume } \\
\cline { 2 - 5 } & \multicolumn{3}{|c|}{ Group I } & \multicolumn{2}{c|}{ Group II } \\
\cline { 2 - 5 } & r & P-value & r & P-value \\
\hline Age & $\mathbf{0 . 1 0 9}$ & $>\mathbf{0 . 0 5}$ & $\mathbf{- 0 . 1 4 4}$ & $>\mathbf{0 . 0 5}$ \\
\hline PLT & $\mathbf{- 0 . 0 2 1}$ & $>\mathbf{0 . 0 5}$ & $\mathbf{- 0 . 1 1 3}$ & $>\mathbf{0 . 0 5}$ \\
\hline ALT & $\mathbf{0 . 1 1 1}$ & $>\mathbf{0 . 0 5}$ & $\mathbf{- 0 . 0 2 9}$ & $>\mathbf{0 . 0 5}$ \\
\hline AST & $\mathbf{0 . 0 5 0}$ & $>\mathbf{0 . 0 5}$ & $\mathbf{0 . 1 9 5}$ & $>\mathbf{0 . 0 5}$ \\
\hline T. Bilirubin & $\mathbf{- 0 . 1 5 7}$ & $>\mathbf{0 . 0 5}$ & $\mathbf{- 0 . 0 8 2}$ & $>\mathbf{0 . 0 5}$ \\
\hline direct B & $\mathbf{- 0 . 1 5 4}$ & $>\mathbf{0 . 0 5}$ & $\mathbf{- 0 . 0 8 1}$ & $>\mathbf{0 . 0 5}$ \\
\hline Albumin & $\mathbf{0 . 0 3 1}$ & $>\mathbf{0 . 0 5}$ & $\mathbf{- 0 . 1 7 3}$ & $>\mathbf{0 . 0 5}$ \\
\hline PT & $\mathbf{0 . 1 5 1}$ & $>\mathbf{0 . 0 5}$ & $\mathbf{0 . 0 3 0}$ & $>\mathbf{0 . 0 5}$ \\
\hline INR & $\mathbf{0 . 1 6 9}$ & $>\mathbf{0 . 0 5}$ & $\mathbf{0 . 0 3 5}$ & $>\mathbf{0 . 0 5}$ \\
\hline S .Cr & $\mathbf{- 0 . 1 2 2}$ & $>\mathbf{0 . 0 5}$ & $\mathbf{- 0 . 0 9 3}$ & $>\mathbf{0 . 0 5}$ \\
\hline Urea & $\mathbf{0 . 0 2 4}$ & $>\mathbf{0 . 0 5}$ & $\mathbf{- 0 . 0 2 9}$ & $>\mathbf{0 . 0 5}$ \\
\hline Na & $\mathbf{0 . 1 6 7}$ & $>\mathbf{0 . 0 5}$ & $\mathbf{0 . 0 6 3}$ & $>\mathbf{0 . 0 5}$ \\
\hline K & $\mathbf{0 . 0 8 2}$ & $>\mathbf{0 . 0 5}$ & $\mathbf{0 . 1 7 8}$ & $>\mathbf{0 . 0 5}$ \\
\hline AFP & $\mathbf{- 0 . 0 8 6}$ & $>\mathbf{0 . 0 5}$ & $\mathbf{- 0 . 0 2 4}$ & $>\mathbf{0 . 0 5}$ \\
\hline TLC in ascitic fluid & $\mathbf{- 0 . 0 1 2}$ & $>\mathbf{0 . 0 5}$ & $\mathbf{0 . 0 4 0}$ & $>\mathbf{0 . 0 5}$ \\
\hline ANC in ascitic fluid & $\mathbf{0 . 0 6 6}$ & $>\mathbf{0 . 0 5}$ & $\mathbf{- 0 . 0 3 6}$ & $>\mathbf{0 . 0 5}$ \\
\hline Protein in ascitic & $\mathbf{- 0 . 0 3 9}$ & $>\mathbf{0 . 0 5}$ & $\mathbf{- 0 . 0 5 4}$ & $>\mathbf{0 . 0 5}$ \\
\hline fluid & & & & \\
\hline
\end{tabular}

ROC curve for the sensitivity and specificity of MPV: At a cut off value of 9.2 fL., MPV had $75 \%$ sensitivity and 99 $\%$ specificity for detecting SBP [AUC=
0.932 with negative predictive value (NPV) and positive predictive value (PPV) for MPV of 79.8 and $98.7 \%$, respectively] (Table 5 and Fig. 1).

Table (5): Validity scores of the MPV in the diagnosis of SBP

\begin{tabular}{|c|c|c|c|c|c|}
\hline Cut off point & AUC & Sensitivity & Specificity & PPV & NPV \\
\hline$>9.2$ & $\mathbf{0 . 9 3 2}$ & $\mathbf{7 5 . 0 0}$ & $\mathbf{9 9 . 0 0}$ & 98.7 & $\mathbf{7 9 . 8}$ \\
\hline
\end{tabular}


Figure (1): Roc curve of MPV in group (I) and group (II)

\section{DISCUSSION}

Spontaneous bacterial peritonitis is a severe and frequent complication of cirrhosis with a high mortality rate. Spontaneous bacterial peritonitis is probably related to several impaired defense mechanisms, such as depressed reticuloendothelial system, phagocytic activity, leukocyte dysfunction, reduced serum complement, and low bacterial activity of ascitic fluid (Riggio and Angeloni, 2009).

Since 1970 when SBP was first described and up to the present, the mortality rate has been decreasing from $80 \%$ to $30 \%$ due to prompt diagnosis and early initiation of antibiotics (Khan et al., 2009). Completely asymptomatic cases have been reported in as many as $30 \%$ of patients (Hadhoud et al., 2012). Symptoms of infection occur in most patients with SBP, including fever, abdominal pain, mental status changes, and ileus. A high index of suspicion should exist for SBP in patients with cirrhosis and ascites (Cekin et al., 2013). Although underlying hepatic disorder, systemic complaints of the patients and ascitic fluid analysis are the cornerstones of the diagnosis, several invasive and noninvasive methods have also been studied for diagnosing AFI in cirrhotic patients (Khan et al., 2009).

This study aimed to compare between result of one of invasive (LESR in ascitic fluid) and non-invasive methods (MPV) for diagnosis of SBP and to compare between LERS as a bed side test and standard PMN counting in the ascetic fluid as regarding efficacy and rapidity in diagnosis of SBP and also use of MPV in the same purpose.

This study was conducted on 200 patients with decompensated liver cirrhosis with ascites with different child classification of which 100 patients showed evidence of SBP (group I) and 100 non SBP (group II) by clinical and laboratory data.

Analysis of the clinical results of the present study revealed that there was no significant difference among patients of different groups as regard age and gender. These results are in agreement with the study of Khan et al. (2009) who stated that no significant differences between patients with SBP from those without SBP.

As regard clinical presentation, this study showed that there was a high statistically significant difference between both groups as regard symptoms, Fever

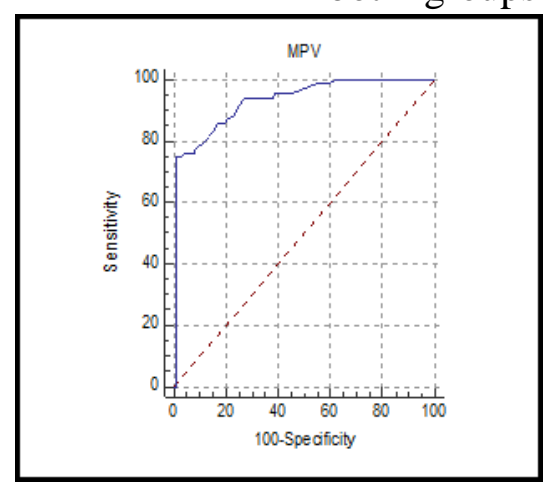

and abdominal pain were more common 
in SBP group and is less than in group II (SBP). These results were in agreement with Lippi et al. (2014) which found that clinical manifestations of SBP are nonspecific, the most frequently encountered symptoms and signs are fever (69\%), abdominal pain (59\%), and less signs of hepatic encephalopathy. Pathak et al. (2014) found that (56\%) of cases had fever and $(54 \%)$ had abdominal pain at time of presentation. Also these results were in agreement with Saqib et al. (2012) who found that the most common presenting symptom was fever $(74 \%)$ followed by abdominal pain (64\%) and Khan et al. (2009) who found that the most common presentation was abdominal pain $(78 \%)$ and abdominal tenderness $(76 \%)$ than fever $(72 \%)$.

According to ascitic fluid analysis in this study there was statistically significant difference between both groups (SBP and non SBP) as regard total leucocytic count (TLC), absolute neutrophilic count (ANC), total protein (TP), culture and sensitivity (C\&S) results and these results were in agreement with the study of Saqib et al. (2012) who showed that the ascitic fluid TLC in patients without SBP was quit low as compared to the patient with SBP.

As regard ascitic fluid culture in SBP group show E.coli and klebsiella were $(59 \%)$ and $(20 \%)$ respectively while culture show no growth in $(21 \%)$. on the other hand, Saqib et al. (2012) Found that only culture positive in (19\%) of patients and Jafri et al. (2019) found that only $35 \%$ was positive .

In this study, the most common isolated organism from culture of ascitic fluid is E.coli (59\%) which in agreement with Doddamani et al. (2010) who stated that E.coli is the most common organism isolated from ascitic fluid in SBP. Also these results were in agreement with that of Koulaouzidis (2011) who showed that the commonest causative agents isolated from infected ascitic fluid were E.coli $(70 \%)$.

In this study, use of reagent strip testing for leucocyte esterase has been proposed to reduce the time from paracentesis to a presumptive diagnosis of SBP from a few hours to a few Seconds (Mendler et al., 2010).

In this study, the test of ascitic fluid by leukocyte esterase reagent strips (LERS) (Urinalysis strips) showed results were in agreement with that of Chugh et al. (2015) which demonstrated sensitivity (96\%) and specificity (89\%) for detecting SBP in cirrhotic patients with ascites. Also, these results were in agreement with that of Fernandez and Gustot (2012) study that showed the Multistix8SG rapid urine screening test had $100 \%$ sensitivity and specificity for SBP diagnosis. In another study, Theovenot et al. (2016) tested the reagent Combur-2 test and showed a sensitivity of $89 \%$ and a specificity of $100 \%$. In the same direction, Sithara et al. (2010) showed results of LERS using the more stringent purple-color cut off to diagnose SBP had a sensitivity of $92 \%$ and specificity of $100 \%$. In contrast, Dever and Sheikh (2015) study showed that sensitivity was only $45.3 \%$. Several explanations are possible for this poor sensitivity. First, published studies were limited to a small number of patients with SBP. Second, the strips were initially designed for detection of urinary tract infections in which the number of 
leukocytes is significantly higher than in SBP.

In this study; Positive predictive value (PPV) and Negative predictive value (NPV) of LERS in diagnosis of SBP were in agreement with that of Bafandeh and Khodaei (2012) which showed those positive and negative predictive values were $91 \%$ and $98 \%$ respectively.

This study showed that the accuracy of the reagent strips to diagnose correctly spontaneous bacterial peritonitis (SBP) was in the same context Chouhan et al. (2018) who studied a group of nonselected paracentesis performed on a cohort of cirrhotic patients, at admission, when an SBP was suspected or was clinically indicated, by use of a reagent strip for leukocyte esterase designed for the testing of urine, the accuracy of the reagent strips was 0.91 (0.87-0.94).

This study showed that there was positive correlation between ascitic fluid polymorph nuclear (PMN) counts and the corresponding result of leukocyte esterase reagent strip test which was statistically high significant. Although, these results were in agreement with that of Honar et al. (2015) study in which a group of nonselected cirrhotic patients were undergone diagnostic paracentesis performed on a cohort of cirrhotic patients were studied at admission, There was a very good correlation between the reagent strip test result and the PMN count, using Aution sticks (ArkrayInc., Edina, Minnesota, USA), It was against that of Riggio and Angeloni (2009) who reported that there was a lack of correlation between the degree of reagent strip positivity and the ascitic PMN counting (Bedside leucocyte esterase reagent strips with spectrophotometric analysis to rapidly exclude spontaneous bacterial peritonitis). In the same direction there were Oey et al. (2016) and Shizuma (2018) This difference in this result may be explained by the reagent strip results were read spectrophotometrically using the clinitek status, thus removing operator subjectivity or indeed error (if color blind). This removes interobserver variability from the diagnostic algorithm. Another explanation that in this study we selected highly suspected patients with SBP while others showed non selected cirrhotic patients for diagnosis. In addition, these strips have only been validated for urine by the manufacturers and numerous factors in ascites, not present in urine, could affect that colorimetric reaction (Koulaouzidis, 2011).

As regard mean platelet volume in our study there was increase in MPV in group of SBP in comparison with non SBP group. There were statistically significant differences between both groups, these results in agreement with Suvak et al. (2015). In our study the diagnostic performance of mean platelet volume showed that we can use MPV as a good diagnostic marker for SBP with high sensitivity, specificity and accuracy. Results showed that the best cut off value for discriminating patients with SBP from patients without SBP was $9.2 \mathrm{fL}$.

\section{CONCLUSION}

The reagent strip testing of ascitic fluid is a very sensitive and specific method for diagnosis of SBP in cirrhotic patients with ascites. It can be used everywhere at the patient's bedside and is rapid, easy to use, inexpensive and results are available within a maximum of 120 seconds. A 
positive result should be an indication for empirical antibiotic therapy, and a negative result excludes SBP and may be useful as a screening test in patients on large-volume paracentesis.

The diagnostic performance of mean platelet volume showed that we can use MPV as a good diagnostic marker for SBP with sensitivity $75 \%$ and specificity $99 \%$ with accuracy $93.2 \%$. And showed that the best cut off value for discriminating patients with SBP from patients without SBP was $9.2 \mathrm{fL}$.

\section{REFERENCES}

1. Abdel-Razik A, Eldars W and Rizk E, (2014): Platelet indices and inflammatory markers as diagnostic predictors for ascitic fluid infection. Eur J Gastroenterol Hepatol., 26:1342-1347.

2. Bafandeh, Y. and Khodaei, M. (2012): Evaluation of leukocyte esterase reagent strip test to detect spontaneous bacterial peritonitis in cirrhotic patients. Gastroenterology Insights, 4(1): e13-e13.

3. Cai, Q., Liu, W., Zhu, M. and Sheng, J. (2019): Microbial Infections as a Trigger for Acute-on-Chronic Liver Failure: A Review. Medical Science Monitor, 25: 4773-4783.

4. Cekin, Y., Cekin, A. H., Duman, A., Yilmaz, U., Yesil, B. and Yolcular, B. O. (2013): The role of serum procalcitonin levels in predicting ascitic fluid infection in hospitalized cirrhotic and non-cirrhotic patients. International Journal of Medical Sciences, 10(10): 1367-1374.

5. Chouhan, P., Dubey, R., Upmanyu, N. and Shrivastava, A. (2018): Update Review Article: Spontaneous Bacterial Peritonitis. Journal of Drug Delivery and Therapeutics, 8(6-s): 384-393.

6. Chugh, K., Agrawal, Y., Goyal, V., Khatri, V. and Kumar, P. (2015): Diagnosing bacterial peritonitis made easy by use of leukocyte esterase dipsticks. International
Journal of Critical Illness and Injury Science, $5(1): 32-7$

7. Dever, J. B. and Sheikh, M. Y. (2015): spontaneous bacterial peritonitisbacteriology, diagnosis, treatment, risk factors and prevention. Alimentary Pharmacology \& Therapeutics, 41(11): 11161131.

8. Doddamani, G. B., Pujar, S. and Kora, S. A. (2010): Spontaneous Bacterial Peritonitis in Ascites: A prospective study in a tertiary care hospital. J Clin Diagn Res., 4: 2737-41.

9. Fernandez, J. and Gustot, T. (2012): Management of bacterial infections in cirrhosis. Journal of Hepatology, 56: S1-S12.

10. Hadhoud, K. M., Ashour, M. A., Basha, O. M., El-Messallamy, F. A., Anwar, A. and Ellatif Hafez, R. A. (2012): Study of Leucocyte Esterase Reagent Strips as a screening test for Spontaneous Bacterial Peritonitis. Life Science Journal-Acta Zhengzhou University Overseas edition, 9(4): 5369-5375.

11. Honar, N., Geramizadeh, B., Dehghani, S. M., Kalvandi, G., Shahramian, I., Rahmani, A. and Javaherizadeh, H. (2015): Evaluation of leukocyte esterase reagent strips test in the diagnosis of spontaneous bacterial peritonitis in children with cirrhosis. Arquivos de gastroenterologia, 52(3): 195-199.

12. Jafri, S., Awan, R. H., Nayab, S. E. E. M. A. and Awan, K. H. (2019): Spontaneous bacterial peritonitis. The Professional Medical Journal, 26(03): 404-408.

13. Khan, Z., Khan, I., Din, J. U., Subhan, F., Khan, B. and Khan, H. (2009): Frequency of spontaneous bacterial peritonitis in cirrhotic patients with ascites due to hepatitis $\mathrm{C}$ virus and efficacy of ciprofloxacin in its treatment. Gomal J Med Sci, 7(2): 149-54.

14. Koulaouzidis, A. (2011): Diagnosis of spontaneous bacterial peritonitis: an update on leucocyte esterase reagent strips. World Journal of Gastroenterology: WJG, 17(9): 1091- 1094.

15. Lippi, G., Danese, E., Cervellin, G. and Montagnana, M. (2014): Laboratory 
diagnostics of spontaneous bacterial peritonitis. Clinica Chimica Acta, 430: 164170.

16. Mendler, M. H., Agarwal, A., Trimzi, M., Madrigal, E., Tsushima, M., Joo, E. and Runyon, B. (2010): A new highly sensitive point of care screen for spontaneous bacterial peritonitis using the leukocyte esterase method. Journal of Hepatology, 53(3): $477-$ 483.

17. Oey, R. C., Kuiper, J. J., Van Buuren, H. R. and De Man, R. A. (2016): Reagent strips are efficient to rule out spontaneous bacterial peritonitis in cirrhotics. Neth J Med, 74: 257 61.

18. Parvizi, J., Jacovides, C., Antoci, V. and Ghanem, E. (2011): Diagnosis of periprosthetic joint infection: the utility of a simple yet unappreciated enzyme. JBJS, 93(24): 2242-2248.

19. Pathak, R., Harsh, S., Adhikari, A., and Khadga, P. K. (2014): Clinical Spectrum of Spontaneous Bacterial Peritonitis in Tertiary Care Centre. Journal of Institute of Medicine, 36(2): 28-32

20. Ponziani, F. R., Zocco, M. A., Cerrito, L., Gasbarrini, A. and Pompili, M. (2018): Bacterial translocation in patients with liver cirrhosis: physiology, clinical consequences, and practical implications. Expert Review of Gastroenterology \& Hepatology, 12(7): 641656.

21. Riggio, O. and Angeloni, S. (2009): Ascitic fluid analysis for diagnosis and monitoring of spontaneous bacterial peritonitis. World Journal of Gastroenterology: WJG, 15(31): 3845-3850.

22. Runyon, B. A. (2009): Management of adult patients with ascites due to cirrhosis: an update. Hepatology, 49(6): 2087-2107.

23. Sánchez, E., Soriano, G., Mirelis, B., Gonzalez, B., Nieto, J. C., Vidal, S. and
Guarner, C. (2015): Effect of long-term acid gastric inhibition on bacterial translocation in cirrhotic rats. European Journal of Gastroenterology \& Hepatology, 27(5): 570576.

24. Saqib, A., Khan, R. R., Masood, Z. and ul Haque, I. (2012): Frequency of spontaneous bacterial peritonitis (SBP) in cirrhotic patients with ascites due to hepatitis B and C. J Uni Med Dent Coll, 3(1): 22-26.

25. Shizuma, T. (2018): Spontaneous bacterial and fungal peritonitis in patients with liver cirrhosis: A literature review. World Journal of Hepatology, 10(2): 254-66.

26. Sithara K., Thomas V. and Sainu, A. (2010): Evaluation of leucocyte esterase reagent strip test for the rapid bedside diagnosis of spontaneous bacterial peritonitis. Indian J Gastroenterol (March-April), 29(2):74-77.

27. Suvak, B., Torun, S., Yildiz, H., Sayilir, A., Yesil, Y., Tas, A. and Kayaçetin, E. (2015): Mean platelet volume is a useful indicator of systemic inflammation in cirrhotic patients with ascitic fluid infection. Annals of Hepatology, 12(2): 294-300.

28. Thévenot $\mathbf{T}$, Briot $\mathrm{C}$, Macé $\mathrm{V}$, Lison $\mathbf{H}$, Elkrief L, Heurgué-Berlot A, Bureau C, Jézéquel C, Riachi G, and Louvet, $A$. (2016): The Periscreen Strip Is Highly Efficient for the Exclusion of Spontaneous Bacterial Peritonitis in Cirrhotic Outpatients. Am J Gastroenterol. (111):1402-1409. 
در اسة منوسط حجم الصفائح الدموية مقارنة بإنزيم الإسنريز

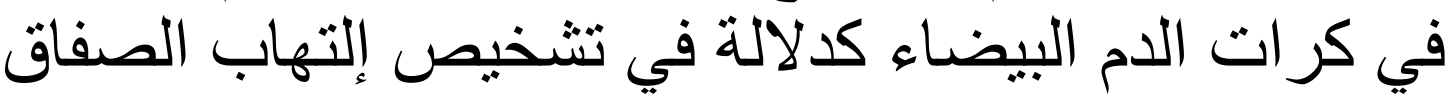
الجرثومي التلقائي

عامر عبد الحميد جمعه *، علي ابراهيم علي سليمان**، أحمد حسن سالم***، محمود

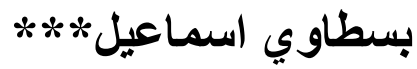

*قسم الجهاز الهضمي و الكبد والأمراض المعدية، كلية الطب، جامعة الأزهر

**قمم الجهاز الهضمي والكبد مستثفى معهز ناصر

***قمس الباتولوجيا الاكلينيكية، كلية الطب، جامعة الأزهر

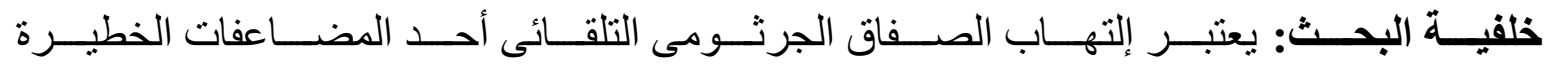

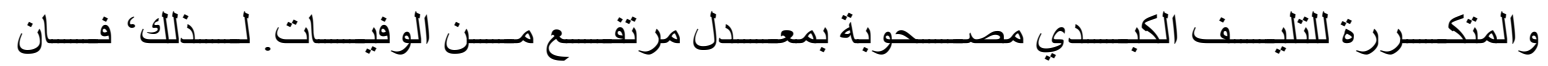
التشخيص المبكر للمرض و علاجه سريعا ضروري لتقليل معدل الوفيات.

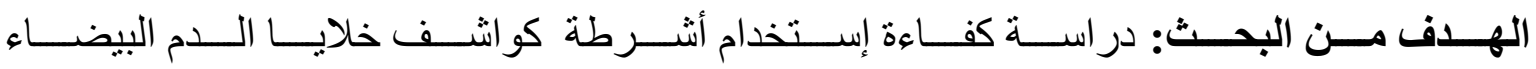

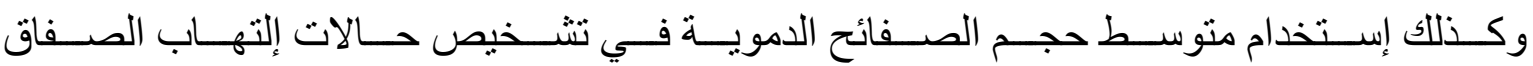
الجرثومى التلقائي.

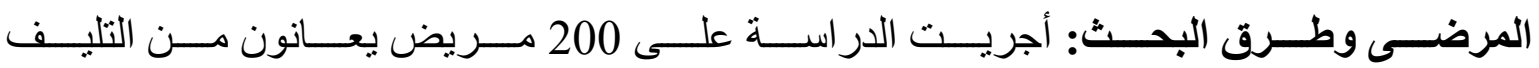

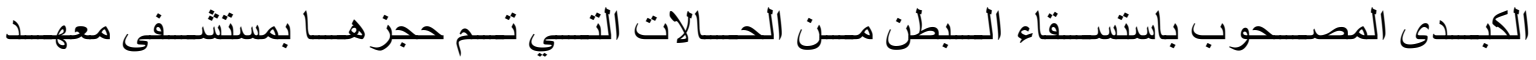

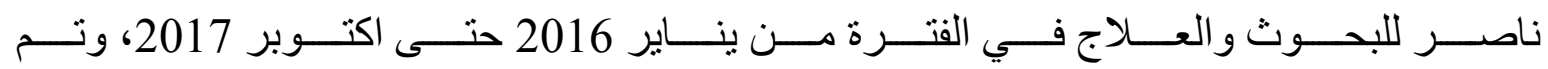

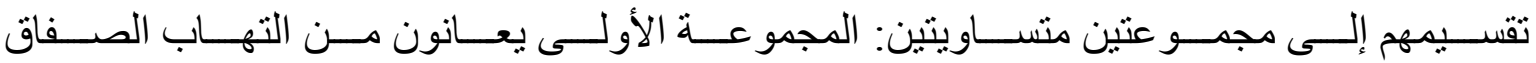

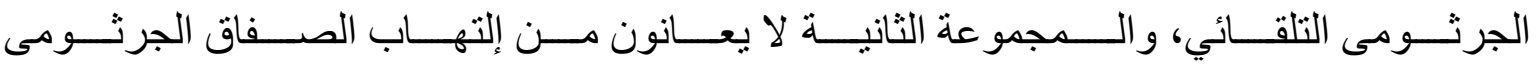

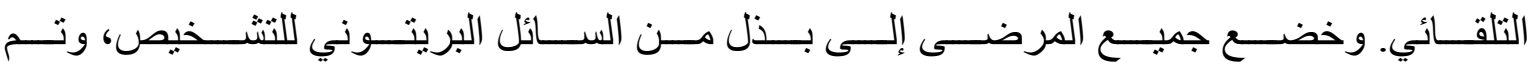

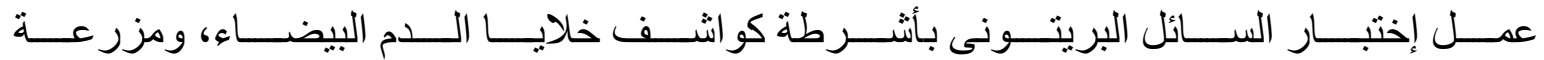

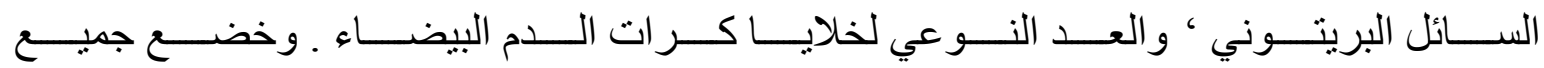
المرضى لتحليل منوسط حجم الصفائح الدموية بصورة الدم الكاملة.

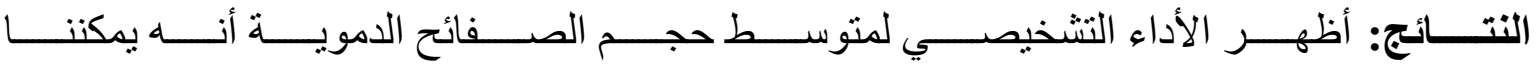

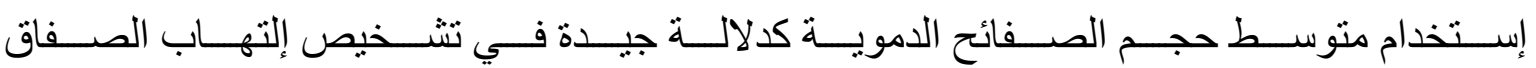




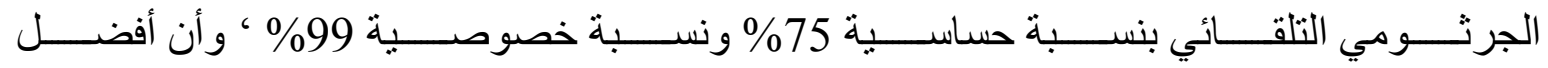

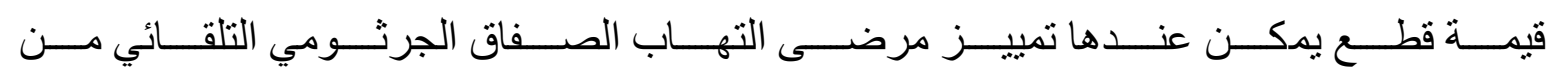

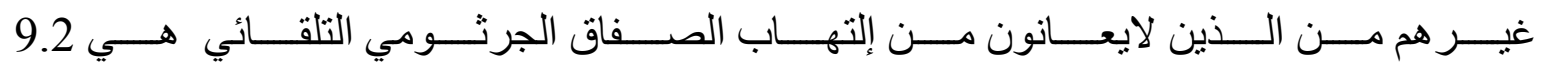

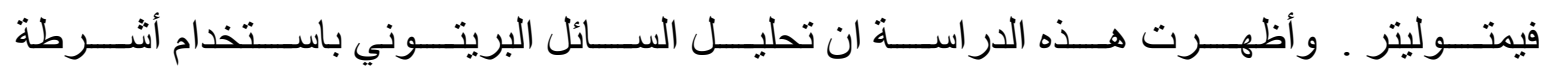

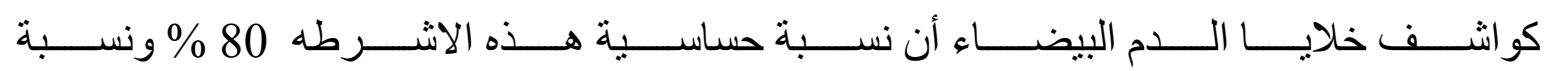
الخصوصية 93 \% ومعدل تنبوْ ايجابي 92\%.

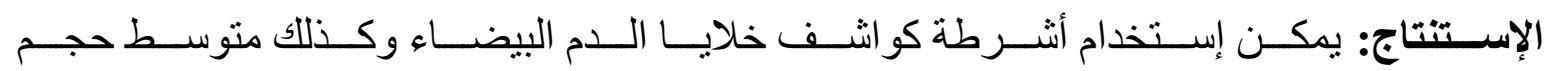

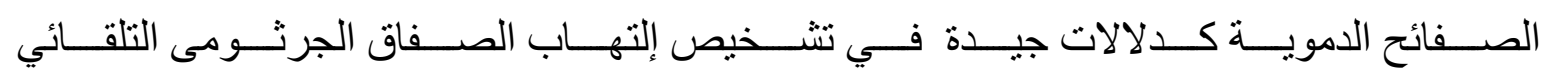
في حالات الإستسقاء بسبب التليف الكبدي. 